\title{
O FENÔMENO DA "ALPHAVILLEZAÇÃO DA CIDADE": A PROLIFERAÇÃO DOS CONDOMÍNIOS FECHADOS ESTUDADA À LUZ DAS INGERÊNCIAS PRIVADAS NA REALIDADE DO MUNICÍPIO DE CAMPINAS
}

\section{THE PHENOMENON OF GATED COMMUNITIES PROLIFERATION: A STUDY UPON REAL ESTATE MARKET INTERFERENCES IN THE REALITY OF CITIES}

\author{
Josué Mastrodi ${ }^{1}$ \\ Marcela Falsoni Sala
}

\section{Resumo}

O presente trabalho tem por objetivo investigar o fenômeno da "alphavillezação" da cidade, que traduz o uso eminentemente privado do território urbano por meio da proliferação de condomínios e loteamentos fechados. Para tanto, estudamos o caso concreto da implementação de um novo megaempreendimento entre o distrito de Barão Geraldo e o bairro de Santa Genebra, no município de Campinas, SP. Neste estudo de caso, identificamos que o planejamento urbano não foi direcionado à efetivação do direito à cidade, mas antes para a satisfação da lógica financeira envolvida na questão habitacional. Apesar de ser vasto o conjunto normativo que trata do direito à cidade, do direito à moradia, e de diretrizes urbanísticas voltadas para a organização dos municípios, foi revelada a insuficiência das normas para atingir os resultados urbanísticos previstos na legislação. O fenômeno da "alphavillezação" da cidade evidencia que, ao lidar com os direitos fundamentais à cidade e à moradia, o Poder Público tende a priorizar interesses privados, subordinando interesses públicos e coletivos aos do mercado imobiliário, o que reforça a segregação espacial no meio urbano e favorece o fenômeno da gentrificação.

Palavras-chave: Direito à moradia, Direito à cidade, Planejamento urbano, Condomínios fechados, Segregação espacial

\begin{abstract}
This paper has the scope to investigate the phenomenon of "alphavillezation" of the city, that is, the urban territory is captured by real estate market not for lessening housing deficit, but for producing wealthy gated communities. Therefore, we studied the concrete case that involves the creation of a new urban area composed by gated communities in the neighborhood of Barão Geraldo in the city of Campinas, SP, Brazil. This research is based upon the case study method, in which it was seen that the urban planning is hardly made to effective the right to the city, but primarily used to satisfy the financial logic involved in the housing issue. Although the set of norms that deals with the right to the city, to housing, and urban planning guidelines, it is possible to observe the insufficiency of this normative set to achieve the expected results. The phenomenon of "alphavillezation" of the city evidences that Public Administration prioritizes private interests when deals with the fundamental rights to the city and to housing, subordinating collective interests to private profit. Consequently, urban segregation is widened, and gentrification is facilitated.
\end{abstract}

\footnotetext{
${ }^{1}$ E-mail: mastrodi@puc-campinas.edu.br

2 Bolsista da FAPESP -- Fundação de Amparo à Pesquisa do Estado de São Paulo. Aluna do programa de Iniciação Científica da Pontifícia Universidade Católica de Campinas. E-mail: marcela.fsala@hotmail.com
} 
Keywords: Right to housing, Right to the city, Urban planning, Gated communities, Urban segregation

\section{INTRODUÇÃO}

O presente estudo tem por objeto a análise do fenômeno da "alphavillezação" da cidade, à luz do caso da criação de um novo bairro entre Barão Geraldo e Santa Genebra, no município de Campinas, SP. A partir do estudo de caso, investigamos a atuação dos agentes do mercado imobiliário na Prefeitura de Campinas objetivando a aprovação e a construção do megaempreendimento denominado "Reserva Dom Pedro". Com base nesse caso, buscamos compreender a proliferação de empreendimentos residenciais fechados no espaço urbano, fenômeno que alcunhamos de "alphavillezação da cidade".

O termo "alphavillezação" remete ao primeiro loteamento residencial fechado de alto padrão construído no Brasil, o Alphaville, e sintetiza o fenômeno pelo qual a cidade transformase em um espaço segregado conforme o critério socioeconômico, por meio da criação de empreendimentos residenciais particulares. Deste modo, a pesquisa examinou o histórico do megaempreendimento imobiliário "Reserva Dom Pedro", um novo bairro composto por uma multiplicidade de condomínios fechados. Apesar de não ser estruturado na forma dos "Alphavilles", pois não será construído com muros altos e uma única portaria para entrada e saída, o megaempreendimento representa a lógica da apropriação dos espaços urbanos pelo mercado imobiliário.

Justamente por esse motivo, selecionamos o caso da criação do "Reserva Dom Pedro" para comprovar a hipótese formulada. A problemática inicialmente versava sobre o planejamento urbano, se este é utilizado para atender às demandas próprias do interesse público, como a promoção dos direitos à moradia adequada e à cidade; ou se estaria de alguma forma a serviço dos interesses do mercado imobiliário, possibilitando a apropriação da terra urbana segundo o seu valor econômico.

Em outras palavras, a pesquisa preocupou-se com a verificação da efetividade do planejamento urbano existente. Partindo-se do pressuposto de que o planejamento é feito pelo poder público, deveria necessariamente ser calcado no interesse público. No entanto, este estudo de caso revelou a priorização dos empreendimentos privados em detrimento da promoção dos direitos fundamentais à moradia adequada e à cidade. 
O caso "Reserva Dom Pedro" permitiu, ainda, a constatação de que o planejamento urbano, nos moldes em que é realizado atualmente, está direcionado à satisfação da lógica financeira e ignora questões graves, como o déficit habitacional, a gentrificação e a segregação espacial.

Em Campinas, houve alguns projetos de criação de novos bairros residenciais em áreas de preservação ambiental: várias áreas privadas do município, com grande extensão, foram apropriadas por incorporadoras imobiliárias. Apenas para exemplificar, foi o caso do "Parque das Araucárias", ${ }^{3}$ empreendimento formado por 103 lotes residenciais, com áreas de 685 a $1.104 \mathrm{~m}^{2}$, e valorizado por $64.000 \mathrm{~m}^{2}$ de área verde, ostentando o título de primeiro loteamento a ser implantado dentro de Área de Proteção Ambiental (APA) de Campinas. Há ainda o "Parque das Sapucaias", 4 que também foi implantado dentro de APA, composto por 79 lotes.

Tais incorporadoras levam ao Poder Público projetos de loteamento urbano visando a implementação de novos bairros de alto padrão, e apresentam os projetos como se fossem assunto de interesse público, distorcendo o real interesse contido nessas ações.

Na verdade, o conceito de qualidade de vida é constantemente explorado pelo mercado imobiliário, que busca proporcionar, exclusivamente àqueles que possuem condições financeiras para adquirir esse padrão elitizado de moradia, o privilégio de habitar uma área verde e de alto padrão, pouco importando os danos causados à coletividade. Nesse contexto, podemos mencionar também o empreendimento "EntreVerdes Campinas", 5 um loteamento dividido em duas fases (EntreVerdes I, com 342 lotes, e EntreVerdes II, com 258 lotes). O loteamento ocupa uma gleba com área total de $3.155 .350 \mathrm{~m}^{2}$ e é composto por lotes de $1.000 \mathrm{e}$ $1.200 \mathrm{~m}^{2}$, distribuídos em 20 condomínios internos.

Isso significa que o "Reserva Dom Pedro" é apenas mais um caso de ingerência privada na realidade imobiliária de Campinas. O problema que se extrai desse quadro é o desejo de exploração econômica de um direito que não alcança a todos. Como não alcança a todos, a moradia adequada passa a ser encarada como privilégio dos que a têm, e não mais como direito constitucional. A proliferação de condomínios fechados, de forma geral, e a implementação do "Reserva Dom Pedro", especificamente objeto deste estudo, são fenômenos que atingem uma

\footnotetext{
${ }^{3}$ http://www.parquedasaraucarias.com.br/ (último acesso em 28/01/2017).

${ }^{4}$ http://www.parquedassapucaias.com.br/ (último acesso em 28/01/2017).

${ }^{5}$ http://entreverdescampinas.com.br/_último acesso em 28/01/2017).
} 
parcela selecionada da sociedade. Consequentemente, a promoção do direito à cidade fica em segundo plano, quando deveria ser prioridade.

Em resumo, a pesquisa buscou responder se há de fato algum interesse público na realização do planejamento urbano pelo qual são definidas tais incursões, ou se estas são voltadas exclusivamente à satisfação de interesses privados. Por meio do estudo, restou confirmado que os interesses públicos relacionados com os direitos à cidade e à moradia não são prioridade da Administração Pública, que age para satisfazer a lógica do mercado imobiliário como se isto fosse verdadeiramente o interesse público que ela deveria promover.

Conforme a análise de Eleusina Freitas, a criação de novos bairros elitizados, bem como a aprovação de condomínios fechados em áreas nobres da cidade, apenas privilegiam interesses particulares e reforçam a segregação espacial urbana, desprestigiando por completo o interesse público:

Empreendimentos cada vez mais fechados e fragmentados espalham-se pelo território urbano invadindo também o rural e a "cidade" da elite toma o lugar do todo. Com a globalização a segregação residencial se acentua assumindo diferentes formas, mais desiguais, mais segmentadas, demarcando espaços de separação entre ricos e pobres, onde não há mobilidade social entre classes. Na representação ideológica da cidade, destacam-se os espaços de distinção e esta representação se torna instrumento de poder (FREITAS, 2008, p. 19).

Cabe destacar que a criação do novo bairro entre Barão Geraldo e Santa Genebra foi, até aqui, barrada por força da atuação de grupos e associações de defesa do meio ambiente, além de existir certa especulação, que imputa ao momento instável da economia e ao desaquecimento do mercado imobiliário, a responsabilidade pelo fato de o megaempreendimento ainda não ter sido implementado. Analisando esses dados com mais profundidade, entendemos que não deveria ser responsabilidade dos grupos de proteção ambiental ou do mau momento econômico evitar a implementação do "Reserva Dom Pedro", já que cabe à Administração Pública não admitir que o espaço urbano seja utilizado para atender a interesses predominantemente privados.

O interesse público demanda ações que minimizem o déficit habitacional, integrem as classes menos favorecidas ao tecido urbano e promovam os direitos à cidade, à moradia adequada e à mobilidade urbana para satisfazer o bem-estar social e garantir a efetivação de direitos. A partir do momento em que se movimenta em sentido contrário, temos uma distorção insuperável do próprio conceito de Administração Pública.

Tratando especificamente do caso estudado para a compreensão do fenômeno da "alphavillezação", o "Reserva Dom Pedro" é um megaempreendimento de magnitude 
alarmante tanto em relação ao aspecto espacial, dada a grande área que pretende ocupar, quanto em relação ao aspecto populacional, uma vez que foi projetado para abrigar uma quantidade considerável de habitantes. Além da segregação espacial típica dos condomínios fechados, o "Reserva Dom Pedro" ainda pode causar grandes impactos no meio ambiente e na dinâmica do tráfego local, tanto que os moradores da região de Barão Geraldo já se manifestaram contra a criação do megaempreendimento. ${ }^{6}$

Deste modo, a pesquisa aponta que o fenômeno da "alphavillezação" da cidade, pelo qual espaços urbanos são separados para loteamento, incorporação e construção de residências de alto padrão, consiste em um modelo de produção de moradias intramuros que se relaciona muito mais com os interesses dos agentes que atuam no mercado imobiliário do que com o interesse público.

Neste sentido, David Harvey afirma que "é importante especificar quem está sendo empreendedor e a respeito de quê" (HARVEY, 2005, p. 171). Para o autor, o real poder de organização da cidade está numa coalizão de forças mais ampla, "em que o governo e a administração urbana desempenham apenas um papel facilitador e coordenador" (HARVEY, 2005, p. 171). Esta coalizão de forças seria a base para a formação do empreendedorismo urbano, por meio do conluio entre "financistas, industriais e comerciantes locais, ou de alguma 'mesa-redonda' entre líderes empresariais e incorporadores imobiliários" (HARVEY, 2005, p. 171).

Assim, o presente artigo busca tornar mais clara a intrínseca relação entre a materialização do direito à cidade e a promoção dos direitos fundamentais, de modo a demonstrar que o interesse social não só pode, como deve afetar os espaços privados, muito embora, na prática, esta não seja a regra.

Neste estudo de caso do "Reserva Dom Pedro", identificamos que o Plano Diretor do município de Campinas e demais normas urbanísticas são insuficientes para impedir que o interesse público seja capturado pelo interesse privado.

\footnotetext{
6 https://coletivocidadaobaraogeraldo.wordpress.com/2014/07/22/reserva-dom-pedro-uma-vitoria-acomemorar/(último acesso em 28/01/2017).

https://secure.avaaz.org/po/petition/Prefeito_Municipal_de_Campinas_Movimento_Contra_os_Novos_E mprendimentos_em_Campinas/_último acesso em 28/01/2017).

http://www.peticaopublica.com.br/pview.aspx?pi=BR72459 (último acesso em 28/01/2017).

https://www.facebook.com/pg/MovimentoEmancipaBarao/photos/?tab=album\&album_id=1407652994 07124_(último acesso em 28/01/2017).

https://www.facebook.com/MovimentoEmancipaBarao/posts/375083562584544_(último acesso em 28/01/2017).
} 
Enfim, o artigo promove uma análise crítica do mercado imobiliário e suas implicações na construção de normas urbanísticas de Campinas, além das consequências na efetivação do direito à cidade e dos direitos sociais que o conformam.

1. O Empreendimento

Os dados sobre o "Reserva Dom Pedro" foram extraídos do Estudo de Impacto Ambiental e do Relatório de Impacto sobre o Meio Ambiente (EIA/RIMA), ${ }^{7}$ ambos submetidos à Companhia Ambiental do Estado de São Paulo e ao Departamento de Avaliação de Impactos Ambientais (CETESB/DAIA), por meio do processo n. 2975/2009.

No primeiro capítulo do EIA são apresentadas as informações gerais sobre o empreendimento, comercialmente anunciado com o nome "Reserva Dom Pedro" e denominado nos documentos como "Plano Urbanístico Gleba A2". O empreendedor é identificado como Fasciata Empreendimentos Imobiliários Ltda., a empresa de consultoria ambiental apontada como responsável é Estúdio de Projetos e Consultoria Ambiental Ltda., e as empresas de projeto urbanístico são Primi \& Appoloni Arquitetura S/C Ltda. e Rossi Residencial S/A.

Ainda no primeiro capítulo, no item "Histórico e Justificativa do Empreendimento", é relatado que, no final de 2006, a Fasciata Empreendimentos Imobiliários Ltda. firmou um contrato particular de compromisso de venda e compra de imóvel urbano com os proprietários do imóvel, com o objetivo de desenvolver na área um empreendimento imobiliário no modelo de loteamentos.

Conforme descrito no EIA, o empreendimento "Plano Urbanístico Gleba A2" é um parcelamento do solo urbano, regido pela Lei Federal n. 6.766/79, de caráter residencial, comercial e de prestação de serviços, que se pretende implantar na área da Gleba A2, antiga Fazenda Santa Genebra, ocupando uma área total de 1.736.725,00 m², com localização junto à Rodovia Dom Pedro I (SP-065, km 138), no distrito de Barão Geraldo.

O distrito de Barão Geraldo está localizado na macrozona 3, que é uma área de urbanização controlada, conforme determina o Plano Diretor de Campinas. É nesse distrito que estão instaladas a UNICAMP (Universidade Estadual de Campinas) e a PUCC (Pontifícia Universidade Católica de Campinas). A Gleba A2 está localizada entre os bairros Jardim Santa Genebra, Jardim José Martins, Jardim Novo Barão Geraldo, Cidade Universitária, Parque das

${ }^{7}$ O EIA/RIMA está disponível no site dos Comitês das Bacias Hidrográficas dos Rios Piracicaba, Capivari e Jundiaí (CBH-PCJ e PCJ FEDERAL) e Comitê da Bacia Hidrográfica dos Rios Piracicaba e Jaguari (CBH-PJ): http://www.comitespcj.org.br/index.php?option=com_content\&view=article\&id=159\&ltemid=118 (último acesso em 28/01/2017). 
Universidades e Parque Rural Fazenda Santa Cândida, e faz parte do perímetro urbano de Campinas.

Para o Plano Urbanístico da Gleba A2, estavam previstos inicialmente, no EIA/RIMA disponibilizado em agosto de 2010, um total de 73 lotes, sendo que destes, 58 seriam lotes residenciais destinados a unidades multifamiliares verticais, com uma estimativa de 7.000 unidades habitacionais; e o restante dos lotes seria destinada a atividades comercial e de prestação de serviços. Nesse momento, a população residente prevista é de 23.940 habitantes, gerando uma densidade de ocupação residencial de 137,85 habitantes por hectare. Ainda, foi realizada a previsão de 1.449 empregados, totalizando uma população de 25.389 pessoas no empreendimento. A área da gleba foi distribuída da seguinte forma: 47,44\% áreas de lotes; 52,56\% áreas públicas, dos quais 10,14\% destinados ao sistema viário; 5,01\% áreas institucionais; e 37,41\% áreas livres de uso público (inclui 32,41\% de áreas verdes e $5 \%$ de sistema de lazer).

O modelo urbanístico de ocupação da gleba foi modificado em maio de $2012,{ }^{8}$ de modo que o empreendimento passou a contar com 80 lotes. Destes, 49 destinados a uso residencial e os 31 lotes restantes são de caráter comercial e de prestação de serviços. Os lotes residenciais serão compostos por unidades horizontais ou verticais, sendo estas formadas pelo andar térreo e mais três pavimentos. O número de unidades residenciais em cada um dos lotes varia de acordo com sua área, estimando-se no máximo 5.000 unidades, cujas metragens variam de acordo com o imóvel: os apartamentos vão de $70 \mathrm{~m}^{2}$ a $230 \mathrm{~m}^{2}$, e as casas de $120 \mathrm{~m}^{2}$ a $200 \mathrm{~m}^{2}$.

Com a alteração, o projeto do loteamento passou a destinar $44,87 \%$ da área da gleba para os lotes; $55,13 \%$ para áreas públicas, dos quais 14,94\% para o sistema viário; 5,51\% para as áreas institucionais; e 34,68\% para áreas livres de uso público (inclui 30,03\% de áreas verdes ${ }^{9}$ e 4,65\% de sistema de lazer). No novo cenário, a população residente prevista é de 17.100 habitantes, com densidade de 98,46 habitantes por hectare. A população empregada prevista é de 3.309 colaboradores, totalizando uma população geral de 20.409 pessoas na hipótese de ocupação máxima do empreendimento.

Segundo o EIA, a implantação do empreendimento seria efetuada em duas fases autossustentáveis e complementares, devido à grande dimensão física da área e à

8 As alterações no EIA/RIMA estão disponíveis no próprio site do empreendimento: http://www.reservadompedro.com.br/ (último acesso em 28/01/2017).

${ }^{9}$ Essa percentagem, que corresponde a quase $1 / 3$ do espaço total da Gleba A2, na verdade se refere ao maciço verde formado pela Mata Santa Genebrinha. Ou seja, não há criação alguma de área verde, apenas a promessa de manutenção da área já existente. 
complexidade da ocupação. Em cada etapa, a intenção é configurar bairros completos, ressaltando-se que, apesar do planejamento prever a entrega em fases, o empreendimento é concebido como um plano geral único. Cabe ainda destacar que, de acordo com o documento que alterou o EIA/RIMA em 2012, o custo para a implementação do empreendimento foi estimado em $\mathrm{R} \$ 32.579 .000,00$ (trinta e dois milhões, quinhentos e setenta e nove mil reais) ${ }^{10}$.

Atualmente, o processo de aprovação da implementação do "Reserva Dom Pedro" ainda está em análise, não tendo sido aprovado até o momento em razão dos pareceres contrários emitidos pelos grupos de proteção ambiental, que afirmam que a aprovação do empreendimento é prejudicial à região de Barão Geraldo, além de contrariar as diretrizes legais de proteção ambiental e planejamento urbano sustentável.

\subsection{A viabilidade da implantação do empreendimento}

A leitura dos documentos permite identificar que o principal objetivo do EIA/RIMA é obter a aprovação do empreendimento, de modo que tanto a forma quanto o conteúdo são voltados para o convencimento dos órgãos responsáveis acerca da viabilidade da implantação. Em vários momentos, há o reconhecimento de que o empreendimento realmente causará impactos à cidade, seja pelo aspecto ambiental ou pelo aspecto urbanístico, até porque seria muito difícil negar a existência desses impactos.

Assim, a tática presente no EIA/RIMA é a de suavizar ao máximo as perturbações que o empreendimento viria a causar, reduzindo-as a um grau de importância mínimo. Trata-se da tentativa de afirmar que, apesar de todos os problemas que o "Reserva Dom Pedro" pode gerar, ainda assim vale a pena aprovar o empreendimento. Por isso, ao longo do EIA/RIMA, são vários os momentos em que se exaltam com veemência as vantagens que poderiam beneficiar a cidade.

É possível perceber, inclusive, que os documentos buscam apontar que não existiria alternativa a não ser aprovar o empreendimento, como se a recusa fosse resultar em uma situação de caos irreversível para a cidade: “(...) a hipótese de não realização do empreendimento não é o cenário mais adequado para a área no presente momento, visto que a região demanda de (sic) empreendimentos deste porte" (EIA, cap. 3, p. 13).

\footnotetext{
${ }^{10}$ Esse valor está distribuído da seguinte forma: topografia e controle tecnológico - $R \$ 720.000,00$; terraplanagem - R\$818.000,00; drenagem de águas pluviais - $\mathrm{R} \$ 3.707 .000,00$; rede de água $R \$ 1.334 .000,00$; adução, booster e reservação de água - $R \$ 230.000,00$; rede de esgoto $R \$ 1.800 .000,00$ elevatórias, emissário - $R \$ 4.200 .000,00$; rede elétrica - $R \$ 1.600 .000,00$; guias e sarjetas americanas $\mathrm{R} \$ 1.000 .000,00$; pavimentação asfáltica - $\mathrm{R} \$ 5.300 .000,00$; recuperação de $\mathrm{APPs}$ e viário $\mathrm{R} \$ 11.000 .000,00 ; \mathrm{e}$ "outros custos" - R\$870.000,00.
} 
Ainda, é interessante notar que o argumento da função social da propriedade ganhou nova roupagem sob a perspectiva do empreendedor, que passa a se comportar como um verdadeiro entusiasta do uso da área da gleba, mas desde que seja para receber o seu empreendimento:

O cenário criado pela hipótese de não execução do projeto seria a existência de um vazio, dentro dos limites da área urbana da Macrozona 3, o que poderia favorecer sua ocupação irregular, gerando um cenário desfavorável em relação aos Planos propostos para áreas com estas características. A atividade agrícola na área também não possui mais importância econômica significativa, não causando maiores impactos (EIA, cap. 3, p. 12).

Segundo essa referência, a implantação do empreendimento não é apenas viável, como também necessária, uma vez que a Gleba A2, segundo seus empreendedores, seria caracterizada como um vazio urbano, e, portanto, a ocupação da área evitaria o avanço da malha urbana sobre os limites da zona rural, possibilitando a preservação desta ao respeitar sua extensão territorial.

No entanto, a verdade é que o vazio representado pela gleba não cumpriu até hoje a sua função social justamente por causa da especulação imobiliária. Toda a área onde se pretende implantar o "Reserva Dom Pedro" não teve a destinação adequada até o momento porque, para os proprietários da Gleba e para os empreendedores, é muito mais vantajoso manter a terra ociosa, aguardando a máxima valorização que o mercado pode proporcionar, do que promover o devido uso do solo de acordo com a função social que toda propriedade deve ter. Definitivamente, a área da gleba deveria ser destinada à satisfação do uso social da propriedade, mas ser ocupada pelo empreendimento não é a única possibilidade, e nem sequer a melhor alternativa existente para o interesse público.

De modo geral, as incursões da iniciativa privada que visam à criação de novos empreendimentos imobiliários no modelo de condomínios e loteamentos fechados apresentam os projetos como se fossem voltados ao interesse público, numa tentativa de demonstrar a adequação dos empreendimentos ao planejamento urbano previsto nas normas urbanísticas, em especial no Plano Diretor do município. No caso do "Reserva Dom Pedro", não há diferença.

Um dos argumentos utilizados pelos agentes de mercado é o de que, diante do crescimento da cidade, o empreendimento é necessário para atender às novas demandas: "A implantação do loteamento urbano aumentará a oferta de imóveis tanto para uso residencial, quanto comercial/serviços, além de promover uma maior integração entre o distrito de Barão Geraldo e o município de Campinas." (EIA, cap.8, p. 58). 
Na mesma página, o Estudo afirma que a o empreendimento deve gerar empregos na fase de implantação e também quando já estiver consolidado, de modo a oferecer trabalho para a mão-de-obra da região. Como consequência, haveria um crescimento da massa salarial de Campinas, aquecendo os demais setores da economia.

Já na página seguinte, é destacada como consequência positiva a arrecadação de impostos, uma vez que, durante a fase de implantação da infraestrutura e edificação dos lotes, haveria aumento na arrecadação de ISS e ICMS. Posteriormente, haveria o recolhimento do IPTU relativo aos imóveis construídos, de modo que a análise é concluída apontando que o "Reserva dom Pedro", se aprovado, promoverá uma elevação significativa da arrecadação de impostos pelo Poder Público, que, por sua vez, teria condições de reverter o montante em investimentos voltados à infraestrutura da cidade.

A promessa de que o novo empreendimento fomentará desenvolvimento econômico, somada ao fato de que o condomínio ou loteamento é comumente apresentado ao Poder Público como um local onde residirão moradores com mais poder aquisitivo, resulta na disputa entre os municípios para receber em seu território os projetos imobiliários privados. Segundo Eleusina Freitas, a concessão de subsídios a novos empreendedores gera uma competitividade urbana, por meio da "guerra fiscal". A autora afirma que a competitividade entre as cidades não se limita na atração de indústrias e comércios, se estendendo aos empreendimentos residenciais privados de luxo. Além da concessão de subsídios diretos, as cidades podem oferecer outros benefícios, como isenção de tributos, leis que flexibilizam o uso do solo, e facilitação dos processos de licenciamento:

A competitividade urbana se insere como definidora dos rumos do crescimento urbano, como única solução possível para resolver a crise social instalada nas cidades, e desta forma consegue convencer a sociedade que o objetivo da política urbana é viabilizar o crescimento através do favorecimento dos interesses das elites capitalistas (FREITAS, 2008, p. 30).

Apesar de todas as promessas de melhorias que são feitas pelos empreendedores, cuja finalidade maior é fomentar essa "guerra fiscal" para obter as propostas mais vantajosas, a referida autora cita Ferreira para afirmar que a atração de empreendimentos não gera uma quantidade significativa de empregos, e que a concessão de subsídios produz impactos negativos para a arrecadação dos municípios (FREITAS, 2008, p. 30).

Do ponto de vista urbanístico, a vantagem oferecida seria a de que "o empreendimento foi desenhado com o objetivo de transcender a prática convencional de mercado", pois o bairro teve sua estrutura voltada para replicar as pequenas cidades e vilarejos, "resgatando, assim a 
qualidade de vida ao se criar lugares especiais para se viver e estimular o convívio em comunidade, priorizando também o pedestre com a diminuição da necessidade do uso de veículos" (EIA, cap. 1, p. 16). Ainda, é afirmado nas conclusões do EIA que a implantação do empreendimento contribui para a consolidação das previsões dispostas nos Planos de Gestão Urbana de Barão Geraldo e Plano Diretor de Campinas, uma vez que o "Reserva Dom Pedro" possibilitaria a urbanização da gleba por meio de um projeto urbanístico integrado, com um plano global de ocupação.

A conclusão, como já se esperava, foi pela viabilidade da implantação do empreendimento, uma vez que o projeto contemplaria toda a infraestrutura necessária, permitindo a ocupação de forma racional e equilibrada, garantindo a preservação ambiental e uma melhor qualidade de vida para a região. Ainda, o EIA afirma que o local onde se pretende instalar o empreendimento está apto a recebê-lo sem que ocorram grandes alterações ambientais na região, prevendo inclusive melhorias, como a consolidação das diretrizes municipais, o que demonstraria a viabilidade da implantação na área escolhida, de acordo com o projeto urbanístico elaborado e programas ambientais a serem executados. (Capítulo 11 do EIA, página 2).

1.2. As demandas geradas pelo empreendimento

Com a alteração do modelo urbanístico de ocupação da gleba em maio de 2012, algumas informações referentes à viabilidade do empreendimento foram modificadas em comparação ao EIA/RIMA, sendo que todas as modificações foram no sentido de confirmar a viabilidade da implantação, haja vista a diminuição dos impactos no novo modelo.

Em relação ao consumo de água, o relatório que contém as alterações afirma que a SANASA (Sociedade de Abastecimento de Água e Saneamento S.A.) deverá atender as necessidades de abastecimento do loteamento por meio de uma linha de alimentação exclusiva, a partir da instalação de um futuro CRD (Centro de Reservação). Caso este ainda não esteja implantado quando o empreendimento estiver em operação, o abastecimento será efetuado de maneira provisória, por meio da Sub Adutora Barão Geraldo, já existente. Devido à queda na população estimada, o relatório considerou o Informe Técnico no 0060-10, apresentado em anexo no EIA e emitido pela SANASA como válido para comprovar a viabilidade de atendimento para o abastecimento de água. O referido Informe Técnico contém a "Diretriz para Estudo de Viabilidade", emitida junto ao Protocolo no 43.020/2009, que analisou o atendimento da nova demanda do empreendimento, prevendo a execução de obras internas 
para o abastecimento de água, coleta de esgoto e outros encargos. No novo modelo de ocupação, a demanda prevista é de 51,99 litros de água por segundo.

A análise do esgotamento sanitário seguiu o mesmo caminho. De acordo com o Informe Técnico, o loteamento pertence ao Sistema de Esgotamento Barão Geraldo, cuja Estação de Tratamento de Esgoto (ETE) já se encontra em operação. O relatório afirma que "durante o processo, também será estudado junto a SANASA, uma solução mista, que possibilite encaminhar parte do esgoto gerado pelo empreendimento para a ETE Barão Geraldo existente, sendo o restante tratado na ETE interna" (página 19 do arquivo de alterações do EIA/RIMA). Para o esgoto, é considerada uma perda de 10\%, em função da demanda total gerada, resultando uma demanda de esgoto estimada em 46,79 litros por segundo.

Considerando a projeção da população total do empreendimento, estima-se que ocorra a produção diária de 14 toneladas de resíduos sólidos, o que corresponde a um acréscimo de $2,14 \%$ da produção diária de lixo no município. A certidão emitida pelo Departamento de Limpeza Urbana da Prefeitura Municipal de Campinas informa que a região da gleba já é atendida pelo serviço de coleta e remoção de lixo com frequência de 6 vezes por semana. ${ }^{11}$ Os resíduos coletados são destinados ao Aterro Sanitário Municipal.

Sob o aspecto da distribuição de energia elétrica, esta seria providenciada pela concessionária local, a CPFL (Companhia Paulista de Força e Luz). Conforme o disposto no capítulo 5o do EIA, os projetos da rede elétrica serão elaborados e implantados pelo empreendedor, sendo doados para a operação da CPFL. Segundo as informações que constam no Estudo, todas as vias do loteamento serão dotadas de iluminação pública, por meio de postes de concreto.

Ainda de acordo com o documento que contém as alterações do EIA/RIMA, no caso do transporte público, ao se tomar como base os trabalhadores estimados para os lotes comerciais, seria possível contabilizar a geração total de 3.309 viagens no transporte público coletivo nos horários de pico. Essa demanda seria atendida pelas linhas que interligam o centro de Campinas a Barão Geraldo.

Um dos pontos mais preocupantes acerca da instalação do empreendimento se refere à sobrecarga do sistema viário e aos impactos que serão causados no trânsito. De acordo com o EIA, o projeto do empreendimento teria a proposta de promover uma urbanização de média densidade na Gleba A2, criando-se uma estrutura independente do centro do distrito de Barão

\footnotetext{
${ }^{11}$ Na verdade, a região da gleba que já é urbanizada possui atendimento. É altamente provável que a nova área urbana, se aprovada, demandaria serviços adicionais de coleta.
} 
Geraldo. Ainda, para minimizar o impacto no tráfego local, foi efetuado o prolongamento da Avenida Guilherme Campos, que conecta a Rodovia Dom Pedro I à avenida Prof. Zeferino Vaz, possibilitando o acesso à PUCC e UNICAMP, além de aliviar o fluxo em direção aos bairros adjacentes.

A implantação desta avenida de interligação se deu por meio do decreto municipal 16.201, de 24 de abril de 2008, que declarou a área destinada à diretriz viária como de utilidade pública, autorizando a desapropriação. Houve também a celebração de um termo de acordo e compromisso com a Prefeitura Municipal de Campinas, no dia 28 de julho de 2008 (protocolo no 2007/11/13.977), que estabelece as obrigações em relação à execução e aprovação da diretriz viária e do Plano Urbanístico pretendido para a Gleba A2.

O estudo de tráfego apresentado no EIA indicou a viabilidade da implantação do empreendimento com o prolongamento já realizado na Avenida Guilherme Campos. De acordo com o estudo, as viagens que serão geradas pelo empreendimento até o décimo ano de sua ocupação, e mais o aumento do tráfego criado pelo crescimento vegetativo pode ser absorvidos pela avenida sem que esta atinja o comprometimento de sua capacidade viária, e a partir desse momento, outras intervenções deverão ocorrer na malha viária do município (EIA, cap. 8, p. 52).

Um dado que salta aos olhos quanto à falta de interesse público na utilização do espaço da Gleba A2 está no fato de que, no projeto do "Reserva Dom Pedro", não há nenhuma previsão de doação de área para construção de equipamentos básicos de serviços públicos, como creche, escola de educação infantil e ensino fundamental, posto de saúde, entre outros. Não é possível considerar que a Administração Pública conseguiria suprir a nova demanda de serviços essenciais de educação e saúde por meio dos equipamentos já instalados em bairros vizinhos à Gleba $A 2$, que já se encontram praticamente saturados por servirem a uma população residente em constante aumento vegetativo.

Ainda que os elaboradores do EIA afirmem que o perfil dos futuros moradores não utiliza de tais serviços, conforme será apontado no item 4, significa apenas que o empreendedor usa de desculpa para não criar contrapartidas em seu loteamento, reduzindo a doação de área exclusivamente para o mínimo necessário, qual seja, lançamento de ruas para permitir a mobilidade dos futuros moradores.

1.3 Impactos ambientais

No primeiro capítulo, ao tratar especificamente das afetações ao meio ambiente, o EIA informa que em 2008 foram elaboradas as diretrizes ambientais, e posteriormente foi 
desenhado o plano urbanístico já otimizando o aproveitamento da área, em razão das restrições preexistentes relativas à minimização dos possíveis impactos.

Além de todas as demandas geradas pelo empreendimento, que foram tratadas no item anterior e necessariamente irão gerar consequências ao meio ambiente, ainda há os impactos ambientais diretos. Estes são abordados no oitavo capítulo do EIA, sendo que se considera como "impacto resultante" o efeito residual final sobre cada componente ambiental afetado, após a execução de todas as ações impactantes e implantação de todas as medidas mitigadoras propostas. A partir dessa observação, os possíveis impactos ambientais foram divididos nas seguintes categorias:

a. Impactos sobre o solo, compreendendo a intensificação do assoreamento das drenagens, instabilização de encostas e problemas geotécnicos, risco de contaminação do solo, e recuperação de processos erosivos como medida mitigadora;

b. Impactos sobre os recursos hídricos superficiais, que abrange alterações na qualidade das águas, elevação das taxas de escoamento superficial, e alteração na disponibilidade hídrica regional;

c. Impactos sobre os recursos hídricos subterrâneos, tratando da contaminação do lençol freático, e redução da recarga do aquífero e rebaixamento do lençol freático;

d. Impactos sobre a qualidade do ar, que contempla o aumento do material particulado, e queima de combustíveis automotivos;

e. Impactos sobre a vegetação, que inclui corte raso (supressão) de vegetação, interferências nos processos de regeneração natural, intervenções em Áreas de Preservação Permanente, a instalação do Parque Linear Ribeirão das Pedras Gleba A2, e a arborização dos sistemas de lazer e passeios públicos;

f. Impactos sobre a fauna silvestre, compreendendo fugentamento e perturbação da fauna silvestre, proliferação de espécies vetores de zoonoses, risco de incêndios florestais, e a eventual melhoria das condições de deslocamento, abrigo e alimentação da fauna;

g. Impactos sobre a qualidade de vida, ambiental local e do entorno, que abarca a indução à alteração do uso do solo no entorno, aumento nos níveis de ruído, degradação das futuras áreas verdes e institucionais do empreendimento, e alteração do uso do solo rural para urbano.

De todos os impactos ambientais apontados acima, são indicados como "positivos" apenas a recuperação de processos erosivos; a instalação do Parque Linear Ribeirão das Pedras 
Gleba A2; a arborização dos sistemas de lazer e passeios públicos; a eventual melhoria das condições de deslocamento, abrigo e alimentação da fauna; a indução à alteração do uso do solo no entorno; e a alteração do uso do solo rural para urbano. Todos os outros impactos são considerados negativos (EIA, anexo "tabelas", tabela 8-1).

Apesar da absoluta maioria de impactos negativos, e ainda considerando que as medidas positivas são apenas uma forma de amenizar as agressões, o capítulo 11 do EIA, ao tratar das conclusões do estudo, basicamente afirma que todo o projeto foi idealizado para produzir impactos mínimos, e que as perturbações inevitáveis seriam reduzidas por meio de medidas mitigadoras:

...a equipe responsável pela elaboração do presente EIA entende que o empreendimento Plano Urbanístico Gleba A2, conforme o projeto básico apresentado demonstra a viabilidade ambiental para ser implantado na área selecionada, pois possibilita a consolidação de diretrizes definidas no Plano de Gestão e Plano Diretor, desde que adotadas os programas ambientais e medidas mitigadoras preconizadas nas diversas fases do empreendimento (EIA, cap. 11, p. 6).

No entanto, o capítulo 9o utiliza 40 páginas apenas para tratar das medidas mitigadoras dos danos causados pelo empreendimento, o que indica que possivelmente os impactos não sejam tão irrelevantes assim.

Diante dos possíveis prejuízos ambientais, foi elaborado um parecer técnico pelos Comitês das Bacias Hidrográficas dos Rios Piracicaba, Capivari e Jundiaí (CBH-PCJ e PCJ FEDERAL) e Comitê da Bacia Hidrográfica dos Rios Piracicaba e Jaguari (CBH-PJ) em dezembro de 2010.12 O parecer aponta que o empreendimento apresenta impactos significativos nos recursos hídricos, sendo que esses impactos não estavam devidamente tratados no EIA/RIMA. Assim, foi realizada uma série de recomendações visando à complementação dos documentos apresentados, além da sugestão de condições para a emissão da Licença de Instalação. Não houve manifestação dos Comitês após a alteração do EIA em 2012.

\section{LEGISLAÇÃO E A QUESTÃO DO USO DO SOLO}

Os interesses públicos e privados no uso do solo urbano são divergentes e resultam da escassez das terras, sendo possível observar verdadeira disputa entre as esferas pública e privada em relação ao uso do solo. Sobre o tema de gerenciamento do crescimento das

\footnotetext{
12 Parecer técnico disponível em: http://www.comitespcj.org.br/index.php?option=com_content\&view=article\&id=272:eia-rima-planourbanistico-gleba-a2-campinas\&catid=62:eias-rima-na-area-do-pcj\&Itemid=118 (último acesso em 24/05/2017).
} 
cidades, cabe citar Feiock et al (2008), para quem as decisões políticas locais refletem um equilíbrio entre os interesses conflitantes, já que são múltiplos os grupos que exercem pressão econômica e política em determinada região. Para os autores, o uso do solo urbano não deve ser tratado de forma uníssona, uma vez que há a necessidade de se examinarem separadamente as múltiplas dimensões envolvidas na gestão do crescimento e na regulamentação do uso da terra; de não se negligenciar o papel que as forças políticas e as instituições governamentais desempenham na gestão do crescimento.

Policy Instrument Choices for Growth Management and Land Use Regulation

Voltando-nos ao estudo do ordenamento jurídico brasileiro, notamos que é vasto o conjunto de normas que tratam do direito à cidade, do direito à moradia adequada, e de diretrizes urbanísticas voltadas para a organização dos municípios. Porém, apesar da existência das normas, esse conjunto normativo é incapaz de produzir os efeitos práticos esperados de maneira adequada. E que, na realidade objeto deste estudo de caso, o equilíbrio apontado por Feiock et al (2008) não se reproduziu por aqui.

A partir da Constituição Federal de 1988, o modelo federativo permitiu que os governos federal, estadual e municipal agissem em relação às questões habitacionais e urbanísticas. Ao município cabe observar as condições locais para promover ao máximo os direitos dos habitantes, dadas as peculiaridades de cada cidade. Não é possível conceber o direito à cidade sem a necessária promoção de políticas públicas, que em regra devem ser efetivadas pela Administração Pública municipal, mas de forma concorrente com a União e com o Estado, nos termos da Constituição da República, artigo 23, inciso IX.

É por esse motivo que existem os meios de intervenção pública nos espaços privados da cidade disponíveis ao Administrador, como o Estatuto da Cidade e o Plano Diretor, que devem ser utilizados para se promover o direito à cidade, de forma geral, e os direitos sociais, em particular. Ainda, a efetivação desses direitos só pode ser assegurada a partir de um planejamento urbano voltado ao interesse público, pois é este planejamento que vai orientar a atuação da Administração no sentido de promoção dos direitos.

Segundo o estudo de Luciana Royer,

(...) a Constituição brasileira, considerada de fato avançada em relação às Cartas Magnas de muitos países, consagrou a moradia como direito fundamental, estabelecendo uma meta a ser atingida pela sociedade brasileira: a universalização do direito à moradia digna. Ousou elevar a meta da política, retirando a conotação individual da habitação como um problema exclusivo dos sem-teto (ROYER, 2009, p. 165). 
De fato, a inclusão da moradia como direito fundamental no texto constitucional traça uma importante meta para os entes federados, na medida em que devem dirigir todos os esforços necessários no sentido de efetivar esse direito, garantindo a todos o acesso à moradia adequada, e consequente integração à cidade. Nesse contexto, ao Estatuto da Cidade coube a regulamentação dos artigos 182 e 183 da Constituição, que tratam da política urbana.

Conforme o artigo 2 ㅇ do Estatuto da Cidade, a política urbana tem por objetivo ordenar o pleno desenvolvimento das funções sociais da cidade e da propriedade urbana, mediante diretrizes gerais, como a garantia do direito a cidades sustentáveis, conformado pelo direito à terra urbana, à moradia, ao saneamento ambiental, à infraestrutura urbana, ao transporte e aos serviços públicos, ao trabalho e ao lazer, para as presentes e futuras gerações .

Esse mesmo artigo 2o prevê também a ordenação e controle do uso do solo, de forma a evitar a utilização inadequada dos imóveis urbanos; a proximidade de usos incompatíveis ou inconvenientes; o parcelamento do solo, a edificação ou o uso excessivos ou inadequados em relação à infraestrutura urbana; a instalação de empreendimentos ou atividades que possam funcionar como polos geradores de tráfego, sem a previsão da infraestrutura correspondente; a retenção especulativa de imóvel urbano, que resulte na sua subutilização ou não utilização; a deterioração das áreas urbanizadas; e a poluição e a degradação ambiental.

O Estatuto, juntamente com a Constituição, redefiniu a função do Plano Diretor, que antes era utilizado como instrumento de definição dos investimentos setoriais municipais, e passou a ser peça básica da política urbana das cidades, responsável pela definição de critérios para o cumprimento da função social da propriedade. Assim, é o Plano Diretor que condiciona os direitos de propriedade no município, e as sanções por seu não cumprimento. O objetivo seria a implementação de uma política fundiária gerada pelo planejamento participativo local, tendo como bases a inclusão territorial, voltada para garantir o acesso dos mais pobres à terra urbanizada e bem localizada, além de assegurar a posse da moradia em áreas ocupadas de forma irregular; a justiça social, pautada na distribuição mais justa dos custos e dos benefícios do desenvolvimento urbano; e a gestão democrática, com a participação efetiva da população na política urbana (ROLNIK et al, 2011, p.131).

Apesar de a Constituição ter previsto expressamente que o Plano Diretor é obrigatório para as cidades com mais de vinte mil habitantes, e do Estatuto da Cidade ter ampliado essa obrigatoriedade para cidades que tenham as características especificadas nos incisos de seu artigo 41, no ano de 2010 houve uma discussão no Supremo Tribunal Federal acerca da obrigatoriedade desse instrumento. O caso que gerou a discussão foi uma Ação Direta de 
Inconstitucionalidade, ajuizada pelo Ministério Público do Distrito Federal e Territórios (MPDFT) em junho de 2007, contra a Lei Complementar do Distrito Federal n. 710/2005, que regula os "projetos urbanísticos com diretrizes especiais para unidades autônomas".

Foi na decisão sobre a repercussão geral do caso que surgiu o debate acerca da obrigatoriedade do Plano Diretor:

O pedido do MPDFT foi apreciado pelos ministros do STF no final de 2010. Segundo a ementa da decisão, a questão constitucional em debate era a "obrigatoriedade do plano diretor como instrumento da política de ordenamento urbano" (...) A redação dá a entender, por exemplo, que o questionamento refere-se à obrigatoriedade da elaboração do plano diretor para os municípios com mais de 20 mil habitantes, ou seja, se o plano diretor é obrigatório ou não (VIOTTO e TAVOLARI, 2016, p. 550).

Já no julgamento de mérito, foi questionada a possibilidade de legislar sobre matéria urbanística sem ser por meio do Plano Diretor. Foi decidido que é constitucional essa forma de legislação, mas desde que seja compatível com o Plano Diretor. O MPDFT não se conformou com a decisão, argumentando que uma lei que trata dos condomínios fechados jamais poderia ser compatível com o Plano Diretor, por violar os princípios e diretrizes da política de desenvolvimento urbano, e contrariar os objetivos fundamentais do artigo 3ำ da Constituição Federal. Para o MPDFT, há uma contradição entre a tese fixada e a decisão que declara a constitucionalidade da lei objeto da ação direta de inconstitucionalidade (VIOTTO e TAVOLARI, 2016, p. 562). ${ }^{13}$

Cientes das exigências legais aplicáveis ao procedimento de implantação do empreendimento, os elaboradores do EIA destinaram o segundo capítulo do Estudo para tratar das normas jurídicas aplicáveis ao "Reserva Dom Pedro" de forma específica. O capítulo é iniciado destacando os artigos da Constituição que tratam da política urbana, e, de certa forma, revela preocupação com o conteúdo dos dispositivos:

(...) os proprietários de áreas situadas em zona urbana ou de expansão urbana, devem se prevenir quanto ao seu aproveitamento, sob pena de terem de submeter-se a destinar suas glebas ao atendimento da função social da propriedade, compulsoriamente, se o Plano Diretor do município assim determinar. O Artigo 182 da CF foi regulamentado pela Lei no. 10.257, de 10 de julho de 2001 (Estatuto da Cidade), que traça as diretrizes gerais da política urbana executada pelo Poder Público municipal (EIA, cap. 2, p. 2).

É justamente em uma gleba ociosa que se pretende instalar o "Reserva Dom Pedro", sendo possível interpretar que, na visão dos empreendedores, até o momento foi oportuno 13 Andamento disponível em: http://redir.stf.jus.br/estfvisualizadorpub/jsp/consultarprocessoeletronico/ConsultarProcessoEletronico.j sf?seqobjetoincidente=3823627_(último acesso em 28/01/2017). 
para a especulação imobiliária a manutenção da ociosidade da propriedade. Entretanto, como neste momento o objetivo é a aprovação do empreendimento, seria uma catástrofe manter a área improdutiva. Conforme observado por Eleusina Freitas,

Estes latifúndios, antigas fazendas de café ou gado, se mantêm improdutivos até os dias de hoje, aguardando o momento propício para se transformarem em lucrativos empreendimentos imobiliários metropolitanos. Localizados entre áreas urbanizadas, e recentemente valorizadas por enormes investimentos estatais em rodovias, tornam-se espaço privilegiado para o mercado imobiliário, promovendo a fragmentação da ocupação do território, o desaparecimento das áreas rurais e a consequente insustentabilidade do processo de urbanização (FREITAS, 2008, p.28).

No mesmo capítulo, o ElA informa que o empreendimento é regido pela Lei 6.766/79, conhecida como Lei do Parcelamento do Solo Urbano, sendo esta a Lei que estabelece os requisitos e as etapas para o parcelamento do solo urbano em lotes, exigindo a criação de novas vias de circulação e espaços de uso comum do povo, destinados ao lazer ou à prestação de serviços sociais. É muito comum, porém, que na prática esses loteamentos convencionais sejam transformados em loteamentos fechados, após a fase de implantação. Isso ocorre porque a Lei 8.736/96, de Campinas, utiliza a permissão a título precário de uso das áreas públicas de lazer e das vias de circulação como forma de permitir a constituição de loteamentos fechados. Esta lei exige apenas a formação de uma Associação de Proprietários, na forma de pessoa jurídica, para conceder a permissão de uso das áreas públicas de lazer e das vias públicas:

Conforme estabelece o artigo 9o da lei 8.736/96, em Campinas, a "permissão de uso e aprovação do loteamento serão formalizadas por decreto do Poder Executivo". Aprova-se o loteamento como aberto, segundo as regras da lei $6.766 / 79$, como se fosse um loteamento convencional, e fecha-se posteriormente mediante autorização especial dada pela Prefeitura Municipal (FREITAS, 2008, p.105).

O artigo 3ำ da Lei do Parcelamento do Solo Urbano prevê que o parcelamento do solo só é admitido para fins urbanos, em zonas urbanas, de expansão urbana ou de urbanização específica, definidas em lei municipal. Para demonstrar que o "Reserva Dom Pedro" está de acordo com a Lei do Parcelamento do Solo Urbano, o EIA aponta que,

(...) a fim de solicitar a Certidão de Uso do Solo, o projeto urbanístico foi protocolado na Secretaria de Planejamento e Desenvolvimento Urbano, junto à Prefeitura Municipal de Campinas, protocolo administrativo no.09/10/46.400 (09/09/2009), sendo que no dia 11/05/2010 foi obtida a Certidão no.06/2010, a qual afirma que o empreendimento está situado na zona $18 \mathrm{BG}$, dentro do perímetro urbano municipal (EIA, cap. 5, p. 2).

De fato, conforme o inciso II do artigo 77 do Plano Local de Gestão Urbana de Barão Geraldo, a Fazenda Santa Genebra, área correspondente ao local de instalação do 
empreendimento, seria uma gleba não parcelada no interior do perímetro urbano, cuja incorporação à malha urbana dependerá de apresentação de projeto global de uso e ocupação do solo para toda a área, a ser submetido à Prefeitura Municipal, seguidas as diretrizes específicas consoantes do Plano Local.

Na Lei de Uso e Ocupação do Solo de Campinas, Lei municipal 6.031/1988, são definidas as zonas de uso do solo nas áreas urbanas e de expansão urbana do município, sendo a zona 18 destinada à proteção de áreas de interesse ambiental e à preservação de edificações de interesse sociocultural. É estabelecido que são consideradas áreas de interesse ambiental aquelas cuja proteção permita preservar a paisagem urbana e a qualidade do meio ambiente, incluindo, entre outros espaços, fazendas, bosques e matas. A Lei estabelece ainda que são consideradas edificações de interesse sociocultural aquelas que possuam valor histórico, cultural, arquitetônico, artístico e turístico, incluindo nesta categoria as edificações tombadas e em processo de tombamento, e outras que vierem a ser indicadas pelos órgãos competentes.

Ainda no segundo capítulo, o EIA menciona o Plano Diretor Municipal de Campinas (Lei Complementar 15/2006) que, dentre outras disposições, estão determinados os objetivos e diretrizes da política de desenvolvimento do município, como a promoção da qualidade de vida da população; redução das desigualdades entre as áreas do município, eliminando os fatores de segregação socioespacial da população de baixa renda, por meio da justa distribuição de infraestrutura e dos serviços públicos; proteção e recuperação do patrimônio ambiental, natural, histórico-cultural e paisagístico; e promoção da justa distribuição dos custos da urbanização e dos benefícios gerados pelos investimentos públicos.

É também no Plano Diretor que está definida a macrozona 3, uma Área de Urbanização Controlada, que compreende o distrito de Barão Geraldo. De acordo com o inciso III do artigo 21, essa macrozona apresenta dinâmicas distintas de urbanização, que demandam controle e orientação para evitar processo de ocupação desordenado. Conforme o EIA, "esta área apresentou um acelerado processo de urbanização nas últimas décadas, sendo que os parcelamentos urbanos regulares são em sua maioria de uso residencial, com predominância de condomínios e loteamentos fechados" (EIA, cap. 3, p. 2).

O Plano Diretor estabelece também que cada macrozona será objeto de no mínimo um Plano Local de Gestão. Assim, a Lei municipal 9.199/1996 instituiu o Plano Local de Gestão Urbana de Barão Geraldo, que estabelece seus objetivos no artigo segundo. Dentre os objetivos, estão ordenar, planejar e incentivar o crescimento urbano de Barão Geraldo, com vistas a garantir a manutenção da qualidade de vida e o desenvolvimento harmônico dessa 
região; definir uma política de uso e ocupação do solo que garanta a qualidade socioambiental por meio do equilíbrio entre os usos urbano e rural, estabelecendo normas e parâmetros para o controle de urbanização da região; e definir diretrizes, instrumentos de gestão, planos e programas prioritários que asseguram a efetividade da proposta urbanística e criem os mecanismos para a implementação das ações recomendadas.

No artigo 6 o do Plano Local, entre outras diretrizes de uso e ocupação de solo, estão a manutenção da paisagem urbana característica de Barão Geraldo com baixas densidades nos diferentes bairros e média densidade no centro; a promoção da distribuição de áreas de uso residencial de forma a atender às diferentes demandas habitacionais geradas pela dinâmica urbana de Barão Geraldo; e a requalificação e valorização dos espaços públicos abertos existentes na área urbana.

A análise das citadas normas indica que, apesar do esforço dos elaboradores do EIA para adequar o empreendimento às disposições legais, na realidade o que há é apenas violação do referido conjunto normativo.

É nítida a tentativa de demonstrar que o "Reserva Dom Pedro" cumpre as determinações legais, pois em vários momentos normas jurídicas são citadas no EIA, e imediatamente é esclarecido que o empreendimento as respeita, quando na verdade ocorre justamente o contrário.

Seja pelas expressões vagas utilizadas nas redações dos dispositivos, que permitem relacionar a maior parte das palavras com as intenções dos empreendedores, sejam pelas possibilidades que o poder econômico e político criam para burlar essas normas, o fato é que seria necessário um contorcionismo muito grande para encaixar a proposta do "Reserva Dom Pedro" na legislação.

De modo geral, as normas tratam um planejamento urbano inclusivo, de maneira a garantir o bem estar social e ambiental, de modo que a cidade apresente sim crescimento, porém de forma ordenada, e garantindo que as peculiaridades de cada região do município sejam respeitadas. Não é possível conceber que um empreendimento com as características do "Reserva Dom Pedro" seja condizente com as diretrizes e regras apontadas. Os impactos ambientais e urbanísticos são inevitáveis, e por mais que se tente minimizá-los, são impactos que impedem a efetivação do direito à cidade e à moradia adequada.

A concretização desses impactos só ocorrerá, na realidade prática, se a implementação do empreendimento for aprovada ao fim do processo. E essa aprovação, por sua vez, só será possível se o planejamento urbano permitir. 
Conforme a análise do conteúdo normativo estudado, a aprovação não deve ocorrer, dada a violação das disposições legais. No entanto, é necessário considerar a hipótese de aprovação, uma vez que não é incomum os interesses políticos e econômicos viabilizarem esse tipo de manobra.

Nesse sentido, se realmente houver aprovação, é porque o planejamento urbano existente é voltado para a satisfação de interesses particulares, e não do interesse público, já que as pautas do interesse público estão voltadas à redução do déficit habitacional e à integração da população à cidade por meio do acesso ao solo urbano, demandas estas que não podem ser solucionadas por meio de um empreendimento da natureza do "Reserva Dom Pedro".

\section{DÉFICIT HABITACIONAL E GENTRIFICAÇÃO}

Considerando que moradia é um direito fundamental, não deveria ser possível admitir que se trata de um direito que não alcança a todos. No entanto, o fato é que muitos sofrem com o déficit habitacional, sendo este um dos maiores problemas a serem resolvidos pelo planejamento urbano.

A pesquisa de Joana Ribeiro e Tomas Moreira apontou que, no ano de 2010, em Campinas, 53.365 domicílios urbanos (15,5\% do total do município) eram informais. Naquele ano, a cidade contava com 234 assentamentos precários, formados por favelas e loteamentos irregulares ou clandestinos que abrigavam pouco mais de 180 mil pessoas, que representam 16,6\% da população total do município. Segundo a pesquisa, o Plano Local de Habitação de Interesse Social (PLHIS) identificou que são necessários $15.989 .250 \mathrm{~m}^{2}$ de terra para as ações de produção de moradias na cidade (utilizando-se como parâmetro $250 \mathrm{~m}^{2}$ por unidade habitacional), e o custo para se atender às necessidades habitacionais seria um valor em torno de três bilhões de reais (RIBEIRO e MOREIRA, 2014, p. 221-224).

Relacionando a questão do déficit habitacional ao empreendimento estudado, temos que o "Reserva Dom Pedro" insere no mercado moradias de alto padrão, e mesmo que haja muitas moradias de alto padrão, esse aumento de oferta não causará a redução do preço das moradias populares. Isso significa que o novo bairro não auxilia na redução do déficit habitacional, sequer de modo indireto. Na verdade, o megaempreendimento desempenha o papel contrário, uma vez que o uso de território, que é escasso, para fazer casas para as classes dominantes, apenas piora o problema. 
Para a redução do déficit habitacional, em primeiro lugar, é necessário que haja solo urbano para receber as moradias de interesse social. Esse tipo de moradia, que deve ser destinada à camada da população que sofre com o déficit habitacional, em regra, não é implementada nas áreas centrais da cidade, dado o elevado valor dos terrenos nessa região. Portanto, o mais comum é que a habitação de interesse social seja instalada na área periférica da cidade, onde o processo de urbanização ainda não está totalmente consolidado.

A partir do momento em que empreendimentos de alto padrão, como o "Reserva Dom Pedro", passam a ser implantados em áreas que potencialmente poderiam servir à redução do déficit habitacional, surge mais um problema, que seria a elevação do valor dessas localidades. Ao receber loteamentos e condomínios fechados, a região acaba ficando mais cara, e deixa de ser uma área que poderia ser destinada à construção de moradias de interesse social. Nesse sentido,

A viabilização de empreendimentos voltados para a elite nas periferias restringe ainda mais a oferta de terras usualmente destinadas às camadas populares, isto é, a possibilidade de se implantar um loteamento fechado em qualquer parte da cidade deflagra um processo inflacionário no preço dos terrenos da cidade como um todo (FREITAS, 2008, p. 87).

Além da elevação do valor da terra, que dificulta o acesso dos mais pobres à moradia adequada e acaba ampliando o déficit habitacional, ocorre também a minimização da atuação do poder público no meio urbanos:

A escassez de áreas de maior qualidade eleva às alturas os preços da terra dessas áreas, mas os preços de terras periféricas sobem também, pois se coloca em curso um motor de especulação imobiliária que não existiria com essa força se a qualidade urbana fosse mais distribuída pela cidade. E, logicamente, quanto maior o preço da terra, menor a capacidade de o poder público intervir como agente no mercado (ROLNIK, 2006, p. 200).

Além da questão do déficit habitacional, outro problema que é majorado pela implantação de empreendimentos de alto padrão é o fenômeno da gentrificação. Basicamente, seria a expulsão de moradores de determinada região da cidade, em razão da especulação imobiliária. Cria-se um loteamento fechado ou condomínio, e os imóveis da localidade, em consequência, sofrem valorização. Desse modo, o custo de vida naquele local também aumenta. Assim, a especulação do mercado faz com que a valorização da região a torne demasiadamente cara para aqueles que moravam no local, que, não suportando a elevação do custo de vida, são obrigados a migrar para regiões mais baratas da cidade. 
Como essa lógica de mercado compromete a capacidade dos moradores de se manterem no território gentrificado, a expulsão destes acaba sendo forçada não por meio de violência física, mas por impossibilidade econômica. No local onde os empreendimentos são implementados, surge um novo centro urbano, pois o poder aquisitivo dos proprietários leva para a região toda a estrutura de circulação de capital, de mercadorias e de serviços. Conforme exposto no EIA, "O Plano Urbanístico Gleba A2 buscou apresentar uma proposta de um bairro auto sustentável em relação às necessidades básicas por demanda de serviço" (Capítulo 3 do EIA, p. 11). Portanto, quem possui condições de morar em um empreendimento privado sempre terá acesso às comodidades urbanas, exatamente porque paga por elas:

A urbanização dispersa tem se configurado nos países periféricos a partir dos processos de expulsão da população trabalhadora das áreas centrais. (...) À periferia precária formada no período industrial, soma-se a nova periferia formada por territórios cada vez mais fechados, destinados ao comércio regional (shopping centers), condomínios de indústrias e escritórios e os loteamentos e condomínios fechados (FREITAS, 2008, p. 30).

Nessa sistemática, os antigos moradores acabam migrando para áreas mais afastadas, e portanto mais baratas, mas também com pouca ou nenhuma condição de garantir o direito à cidade. Segundo a observação de Raquel Rolnik, é no centro que estão localizadas as residências da classe média, devidamente regularizadas pelo registro em cartório, sendo que é também na região central que se encontra a infraestrutura de comércio, lazer, serviços e cultura. Já na periferia estão localizadas as moradias irregulares, raramente registradas, sendo nestas habitações majoritariamente precárias em que residem os mais pobres (ROLNIK, 2006, p. 201).

De acordo com a pesquisa de Josué Mastrodi e Suzana Maria Loureiro Silveira, é o valor da terra que justifica a exclusão de parte da população do tecido urbano, de modo que a habitação popular passa a ter sua produção viabilizada apenas em zonas periféricas, dada a maior possibilidade de se auferir lucro com a construção. Por meio desse modelo de ocupação do solo, as fronteiras do que se considera cidade são expandidas, e a população de baixa renda se vê cada vez menos integrada ao tecido urbano. Para os referidos autores, a distância das residências populares em relação ao centro da cidade dá origem ao movimento pendular, pois as atividades cotidianas como trabalho, estudo e lazer exigem a migração diária dos habitantes das periferias para a região central, com o posterior retorno para suas casas, que funcionam apenas como dormitórios (MASTRODI e SILVEIRA, 2016, p. 23-24). 
Tanto o déficit habitacional quanto a gentrificação são fatores que comprometem a efetivação do direito à cidade. $E$, ao tratar de direito à cidade, cabe esclarecer que um de seus pilares é o direito à moradia adequada, e moradia adequada não é apenas teto, chão e paredes. Moradia adequada é aquela que garante acesso aos outros direitos fundamentais, além da moradia em si. Desse modo, não basta um local para morar, pois este local, além de servir como abrigo, deve também servir de instrumento para que o cidadão exerça os demais direitos fundamentais proporcionados pela moradia.

Portanto, a gentrificação e a consequente imposição de se viver nos locais mais baratos da cidade, ou até mesmo em ocupações, que geralmente são afastadas e com pouca ou nenhuma estrutura habitacional, faz com que os moradores dessas áreas fiquem impossibilitados de exercer o direito fundamental à moradia adequada e o direito à cidade.

Para ilustrar de forma mais clara a questão da moradia adequada, importante destacar o estudo de Raquel Rolnik e Jeroen Klink, em que está presente uma pesquisa com metodologia capaz de dimensionar qual é o percentual dos domicílios de um município em que exista uma infraestrutura considerada básica. No meio urbano, os critérios utilizados para considerar o domicílio adequado são: possuir rede geral de abastecimento de água canalizada em pelo menos um cômodo; iluminação elétrica; rede geral de instalação sanitária; lixo coletado por serviço de limpeza diretamente; número de banheiros maior que zero; ser um domićlio particular permanente; localização fora de aglomerado subnormal; e ter densidade igual ou menor a dois moradores por cômodo; sendo que é considerado adequado o domicílio que não apresentar nenhuma inadequação.

No ano 2000, apenas 33\% dos domicílios do Brasil eram totalmente adequados; 30,5 milhões de domicílios apresentavam alguma inadequação, e nenhum município do Brasil tinha 100\% dos domicílios adequados. Na projeção da pesquisa, a porcentagem de domicílios adequados cresceria apenas 12,63 pontos no período de 2000 a 2008. Chama a atenção a precariedade identificada na região Sudeste, que contava apenas com metade de seus domicílios totalmente adequados em 2000 e 65\% na projeção de 2008. É nesta região, considerada a mais próspera e estruturada do Brasil, que se encontra a maior densidade de domicílios e de cidades populosas, o que permite concluir que "a desigualdade sócio espacial tem uma clara expressão regional, mas tem também uma dimensão - interurbana - persistente no modelo de desenvolvimento urbano do país" (ROLNIK e KLINK, 2011, p. 6-9).

Nesse sentido, a pesquisa revela que a criação do megaempreendimento não decorre de interesse público, pois o objetivo não é a redução do déficit habitacional, nem a melhoria das 
condições de vida dos atuais moradores da cidade. Não se busca a efetivação do direito à cidade, pois é evidente que o novo bairro não possui o condão de expandir o grupo de pessoas selecionadas que, além de serem titulares desse direito, ainda possuem de fato as condições necessárias para exercê-los. Direitos à moradia e à cidade são direcionados a todos, pois assim determina o texto constitucional. A grande dificuldade é a promoção de um cenário urbano em que as pessoas consigam de fato exercer esses direitos sem terem de pagar por isso segundo a lógica do mercado imobiliário.

Para abandonar a condição de mera titularidade e proporcionar o nível de real exercício dos direitos à moradia e à cidade, é necessário que sejam implementadas políticas públicas para a inclusão daqueles que ainda não chegaram a esse ponto de pleno exercício desses direitos. Não basta assegurar formalmente a existência de direitos fundamentais, se não são oferecidas as condições de efetivação destes. Contraditoriamente, percebemos que o planejamento urbano não leva em consideração a promoção desse contexto de efetivação de direitos. Na realidade, a postura do poder público é muito mais voltada à garantia do bom funcionamento do mercado que à busca pela promoção de direitos constitucionais.

Voltando ao empreendimento estudado, uma vez que não há interesse público na criação do "Reserva Dom Pedro", visto que só haveria interesse público se o direito à cidade fosse ampliado por meio da implantação do empreendimento, resta óbvio que seu objetivo é satisfazer a lógica capitalista do mercado imobiliário. No caso de aprovação do projeto, seria necessário que houvesse, minimamente, a imposição de contrapartidas ao empreendedor.

Já que a aprovação do empreendimento há de gerar imensas vantagens aos agentes de mercado, e ainda causar prejuízo às questões urbanas apontadas, como o déficit habitacional e a gentrificação, o que só por isso já imporia à Administração Pública que negasse aprovação ao projeto, deveriam ser criados mecanismos para reduzir os danos e tentar reconstituir uma situação que, apesar de ser desequilibrada, ainda assim seja mais equilibrada do que o cenário que será formado com a aprovação do empreendimento.

\section{O EXERCÍCIO DOS DIREITOS À CIDADE E À MORADIA}

O estudo da dinâmica de funcionamento do mercado imobiliário esclareceu que empreendimentos da natureza do "Reserva Dom Pedro" podem ser considerados como um instrumento para se garantir, apenas para uma reduzida parcela selecionada da sociedade, a efetividade dos direitos à cidade e à moradia. De certa forma, seria uma contribuição para a 
manutenção dessa realidade de exclusão, já que o processo de urbanização das cidades brasileiras é segregacionista desde sua origem, e assim se mantém até a atualidade. Conforme a explicação de Raquel Rolnik:

Em um dos movimentos socioterritoriais mais rápidos e intensos de que se tem notícia, a população brasileira passou de predominantemente rural para majoritariamente urbana em menos de 40 anos (1940-1980). Este movimento - impulsionado pela migração de um vasto contingente de pobres - ocorreu sob a égide de um modelo de desenvolvimento urbano que basicamente privou as faixas de menor renda da população de condições básicas de urbanidade, ou de inserção efetiva na cidade (ROLNIK, 2006, p.199).

Assim, as cidades se formaram a partir de uma estrutura urbana que posicionou as classes socioeconômicas dominantes nas áreas privilegiadas da cidade, e as classes mais frágeis nos locais precários do ambiente urbano. Para além disso, a cidade sempre foi construída no território ocupado pelos mais ricos. Equipamentos públicos, planejamento urbano, se houve, foi prioritariamente nessas áreas. Esse crescimento predatório das cidades foi causado tanto por causa da utilização das leis como instrumento de arbitrariedades, quanto por causa do patrimonialismo, que levou à captura do poder público pelo interesse privado. Essas distorções proporcionaram, inclusive, que os governos locais aceitassem o descumprimento de normas para favorecer empreendedores que atuam no mercado imobiliário. Como bem observou Eleusina Freitas, "a propriedade privada de terra tornou-se poder político, econômico e social. Nesse contexto, a lei é usada como moeda de troca e instrumento de dominação, o que permite excluir grandes parcelas da população da cidade legal" (FREITAS, 2008, p. 26).

Nesse cenário histórico de exclusão socioespacial, o Brasil passou a receber em suas cidades a habitação em condomínios e loteamentos fechados, tendo como principal referência os subúrbios norte-americanos. Quando surgiram nos Estados Unidos, os subúrbios representavam uma forma de se afastar não só da poluição das fábricas, mas também dos operários que moravam na região industrializada.

Seguindo a mesma lógica, os empreendimentos fechados na atualidade brasileira oferecem aos compradores o rompimento com o resto da cidade pois, além das barreiras físicas, ainda promovem uma atmosfera de exclusividade, criando um mundo ilusório intramuros, ocupado por moradores padronizados que pertencem ao mesmo grupo socioeconômico. Além de oferecer essas vantagens aos moradores, os condomínios oferecem benefícios também aos empreendedores, dada a altíssima rentabilidade desse novo modelo de empreendimento. Mais do que um lote, o que se oferece ao consumidor é a prestação privada 
dos serviços que antes eram de responsabilidade do poder público, como segurança, lazer e manutenção urbana.

A combinação desses fatores, que podem ser resumidos nas vantagens percebidas tanto pelo consumidor quanto pelo empreendedor, possibilita o entendimento de que a privatização da cidade ocorre de forma intencional, ou seja, não se trata de um processo que ocorre ao acaso. Consequentemente, "as regras para a ocupação do território são agora, mais do que nunca, ditadas pelo mercado. Onde houver maior interesse econômico haverá ocupação urbana" (FREITAS, 2008, p. 49).

Depreende-se da pesquisa que o grande problema desse modelo de mercantilização da habitação é que só estão inclusos nessa dinâmica aqueles que possuem condições financeiras para consumir a mercadoria "moradia" que os empreendedores lançam no mercado. E a partir do momento em que essa mercadoria é, em sua essência, um direito fundamental, a efetividade desse direito é assegurada apenas a quem pode pagar por ela:

O cidadão beneficiário de direitos passa a ser encarado como um consumidor e a questão habitacional, como uma questão individual de quem pode ou não pode tomar crédito, de quem pode ou não oferecer garantia contra os riscos temidos pelos agentes financeiros. (ROYER, 2009, p. 164).

Segundo Tarcyla Fidalgo Ribeiro, apesar das previsões legais, dos estudos técnicos e da previsão constitucional imperativa, o planejamento urbano não apresenta a efetividade desejada em razão da falta de vontade política. Assim, se aproxima mais de uma função meramente discursiva, continuando distante da realidade social. A autora afirma que, no Brasil, o planejamento urbano sempre esteve subordinado aos interesses do capital imobiliário, servindo como instrumento de dominação das classes dominantes e até mesmo como instrumento justificador de violações de direitos nas regiões periféricas. Essa instrumentalização do planejamento urbano é causada justamente pela alienação em relação à realidade social, que deve ser combatida para que o planejamento urbano tenha efetividade em ordenar o espaço visando às melhores condições de habitabilidade para todos os moradores da cidade (RIBEIRO, 2012, p. 81-82).

As principais medidas para se alcançar essa efetividade seriam a garantia do espaço público e o incremento da participação democrática. Como exemplo do movimento de privatização do espaço público, a autora cita os condomínios fechados, que são espaços privados que possuem regras próprias de convivência e resultam em um "poder paralelo" ao do Estado, acentuando a segregação social e econômica, além de reduzir o senso de comunidade dos moradores, que deixam de se enxergar como parte da cidade. Quanto à participação 
popular no planejamento urbano, mesmo sendo nula, seria decisiva para a efetividade dos projetos, devido às experiências da população que vive onde se pretende intervir. Para a autora, o maior desafio do planejamento urbano é conquistar autonomia em relação aos interesses das elites e do capital imobiliário e se reaproximar da realidade social, de modo a realmente promover o direito à cidade (RIBEIRO, 2012, p. 86-89).

No caso específico do "Reserva Dom Pedro", os futuros imóveis não serão ocupados por aqueles que realmente sofrem com o déficit habitacional na cidade, pois o padrão das moradias a serem disponibilizadas é direcionado para uma classe socioeconômica que possui condições de adquirir a própria moradia. Isso significa que o "Reserva Dom Pedro", assim como os demais loteamentos e condomínios de alto padrão, tem como público-alvo pessoas que já possuem os direitos à moradia adequada, à mobilidade urbana e à cidade consolidados e assegurados. São pessoas que já habitam moradias de qualidade, já circulam pelo meio urbano sem dificuldades, e já ocupam a cidade e fazem uso pleno desta, sem sofrer qualquer tipo de exclusão ou violação desses direitos. Conforme descrito no EIA:

(...) o porte dos lotes permite muitas vezes a implantação do lazer na própria residência, podendo ainda haver um pequeno aumento na demanda por equipamentos de lazer existentes na área de influência do empreendimento, shoppings e ainda gerar um amplo crescimento no segmento de lazer gastronômico em ampla ascensão no distrito de Barão Geraldo (EIA, cap. 8, p. 57).

Essa constatação presente no Estudo revela que os potenciais consumidores dos imóveis são aqueles que pertencem às classes média e alta, e justamente por possuírem este perfil, estão aptas a serem consumidoras das unidades habitacionais, seja para efetivamente morar, ou mesmo para investir e fomentar a especulação imobiliária. Reforçando esse caráter de seletividade do empreendimento, os elaboradores do EIA, ao tratarem da eventual demanda por novos equipamentos públicos voltados para a educação, afirmaram que:

(...) parte dos compradores do empreendimento são oriundos da classe média alta, que tradicionalmente procuram a rede privada de ensino. Semelhantemente, o cálculo da demanda a ser gerada sobre os equipamentos de educação pública considera que os futuros moradores são, em sua maioria, oriundos da própria região de Campinas, não representando incremento da demanda. A classe social a que pertencem indica que tal incremento de demanda ocorrerá principalmente no sistema de ensino privado (EIA, cap. 8, p. 56).

Por outro lado, quem não possui o perfil de consumidor do "Reserva Dom Pedro" são aqueles que não têm acesso à moradia na Região Metropolitana de Campinas. São pessoas que, em regra, dependem de programas de produção de habitação de interesse social para terem 
assegurados o seu direito à moradia adequada e à cidade. No entanto, há grande dificuldade em serem elegíveis para conquistar uma moradia popular, por falta de condições econômicas.

o questionamento que surge, diante desse cenário, é o motivo pelo qual o poder público investe seus recursos para levar infraestrutura urbana às localidades que receberão empreendimentos fechados (ruas e estradas pavimentadas, iluminação, transporte público na região, entre outros), em vez de destinar os mesmos recursos à efetivação do direito à moradia e do direito à cidade. A Administração, fundamentalmente, deve se movimentar no sentido de atender ao interesse público e concentrar os seus esforços na redução do déficit habitacional, e não canalizar as suas ações para atender às demandas do mercado imobiliário.

Como resultado dessa postura do poder público, observamos uma cidade dividida em regiões bem definidas: de um lado, há os espaços com alta qualidade de vida, em que os direitos fundamentais dos moradores são assegurados, já que estes puderam pagar por eles; e de outro, espaços mal estruturados, com baixa qualidade de vida, em que não há efetivação dos direitos fundamentais dos moradores. Conforme a descrição de David Harvey, "A paisagem criada pelo capitalismo também é vista como lugar da contradição e da tensão, e não como expressão do equilíbrio harmonioso" (HARVEY, 2005, p.55).

5. A produção privada de moradia

Mais um ponto apurado pela pesquisa que demonstrou a ineficiência em garantir a efetividade dos direitos fundamentais é o fato de que o poder público concentrou a produção de moradia de interesse social nos empreendedores ligados ao capital financeiro. Deste modo, mecanismos jurídicos e institucionais são responsáveis por promover e ampliar a consolidação da produção privada de moradias no Brasil.

Por meio de manobras junto ao governo, o mercado imobiliário passou a ocupar o papel principal na política brasileira de habitação. Segundo a tese de Lúcia Shimbo, esse fenômeno é impulsionado pela entrada do capital financeiro no sistema habitacional:

A relação entre política pública habitacional e produção privada de moradias jamais deixou de existir no Brasil. No entanto, ela se redesenhou com a entrada do capital financeiro nas grandes empresas construtoras e incorporadoras e com o aumento de recursos dos principais fundos públicos e semipúblicos - o Fundo de Garantia do Tempo de Serviço (FGTS) e o Sistema Brasileiro de Poupança e Empréstimo (SBPE) -, do Sistema Financeiro da Habitação (SFH), a partir de meados dos anos 2000 (SHIMBO, 2010, p. 23).

Assim, o acesso à moradia popular passou a enfrentar mais uma barreira, representada pelo modelo de política habitacional baseada no financiamento da compra de novas unidades, vigente desde a criação do Banco Nacional da Habitação (BNH) em 1964, ano em que também 
foi instituído o Sistema Financeiro de Habitação (SFH). Esse modelo excluiu a parcela da população que possui renda média familiar de até 3 salários mínimos, sendo nesta faixa que se concentra aproximadamente $90 \%$ do déficit habitacional. Consequentemente, essas pessoas não exercem o direito à moradia adequada por não conseguirem acessar o mercado imobiliário (ROLNIK e KLINK, 2011, p. 17).

No artigo intitulado "O aquecimento imobiliário e o mercado de habitação na área central de São Paulo", Lucia Shimbo trata do consumo das moradias produzidas pelo setor privado. Para a autora, desde 2006, houve um crescimento dessa forma de produção por causa do aumento do poder aquisitivo da população, o que possibilitou um maior acesso ao crédito habitacional. Ao mesmo tempo, o processo de financeirização do mercado imobiliário levou as construtoras e incorporadoras a terem como foco a produção de unidades com preço de até $\mathrm{R} \$ 200.000,00$ (duzentos mil reais), com área útil de $50 \mathrm{~m}^{2}$, destinada a essa faixa de consumo em ascensão, representada por famílias com renda igual ou inferior a 16 salários mínimos (SHIMBO, 2013, p.224). Essas famílias podem acessar subsídios públicos ou não, mas necessariamente acessam o crédito imobiliário.

A autora afirma que o consumo desse padrão de habitação foi incentivado pelo poder público via crédito habitacional, potencializado pela entrada de capital financeiro nas empresas. Via de regra, as unidades produzidas são organizadas em condomínios horizontais dentro de um perímetro murado; ou em empreendimentos verticais compostos por edifícios de até cinco pavimentos; ou em empreendimentos verticais contendo edifícios acima de cinco pavimentos. De acordo com o estudo,

Nos três tipos, prevalece a concepção de "condomínio-clube", modelo até então adotado para os empreendimentos de alto-padrão, mesmo que a área de lazer seja bastante restrita e não haja espaços de consumo e de trabalho, como ocorre naqueles voltados para as camadas de renda mais altas. Na maioria dos empreendimentos do segmento econômico, localizados nas capitais e nas cidades do interior do Brasil, o financiamento a clientes ocorre via CAIXA - mais recentemente, concentrado no PMCMV (SHIMBO, 2013, p. 230).

Isso significa que, a partir do momento em que o mercado privado se incumbe de produzir habitação, o objetivo maior é obter lucros e minimizar riscos. E essa lógica restringe ainda mais a oferta de moradias às famílias que sofrem não só com o déficit habitacional, mas também com a dificuldade de conseguir crédito para financiar uma unidade residencial. $O$ padrão de moradia intramuros, seguindo o modelo de "condomínio-clube", atingiu inclusive a chamada Habitação de Mercado Popular, demonstrando que, definitivamente, não há espaço para a produção de moradias que atendam as camadas socioeconômicas mais vulneráveis. 
A pesquisa de Luciana Royer, ao tratar da "financeirização" da política habitacional, indica que a presença dos agentes privados no mercado imobiliário passou a determinar a configuração da cidade. Neste sentido, afirma a autora:

Inicialmente compreendida como política de bem estar, a provisão habitacional migrou paulatinamente do discurso universalista dos direitos fundamentais para a lógica seletiva dos mercados, articulando-se de maneira inovadora com a arquitetura financeira dos novos padrões de acumulação do capital (ROYER, 2009, p. 13).

Sob essa perspectiva, é o mercado quem está ditando as regras do planejamento urbano, e, dessa forma, a "financeirização" da política habitacional causa impactos negativos no acesso à moradia, que será provida apenas àqueles que se adequarem às imposições dos agentes imobiliários. Portanto, a solução para o déficit habitacional definitivamente não virá do mercado financeiro.

Embora a produção de moradia realmente tenha sido assumida majoritariamente pelas instituições privadas, o Estado não foi excluído do processo. Ainda de acordo com o estudo de Luciana Royer, a criação do SFH demonstra o papel fundamental desempenhado pelo Estado na instituição e na articulação do sistema de crédito habitacional, sendo que, nesse cenário, cabe ao poder público garantir a dinâmica do setor imobiliário e das políticas públicas de habitação: "a intervenção do Estado em prol da acumulação de capital e da apropriação privada do excedente, no entanto, não é um traço inovador dos sistemas de financiamento da habitação no Brasil” (ROYER, 2009, p. 160).

Para a autora, o discurso de que o mercado deve ser o grande responsável por solucionar o déficit habitacional brasileiro não passa de um processo de falsificação, uma vez que critica um Estado de Bem Estar Social que nunca foi efetivo, e ainda atribui ao mercado a capacidade de lidar com um problema crônico como o déficit habitacional, quando na verdade o interesse das instituições privadas é o acesso aos recursos públicos para a obtenção de lucro. Esse discurso sustenta o sistema e faz com que os direitos sejam "distribuídos a quem esteja devidamente qualificado pelo mercado para recebê-lo" (ROYER, 2009, p. 165).

Uma análise no mesmo sentido foi realizada por Lúcia Shimbo, que atribuiu ao Estado a função de criar a demanda para o consumo das unidades habitacionais produzidas pelas empresas privadas, além de alimentar o capital de giro dessas empresas promovendo os financiamentos à sua produção. O Estado garante diversos mecanismos jurídicos e regulatórios, formatando um aparato institucional que gera segurança e credibilidade para a atuação do mercado imobiliário na produção de habitação social. O que se observa, portanto, é uma articulação entre Estado e mercado, que se desenvolve a partir da lógica privada de produção 
da habitação, quando se encara a moradia como mercadoria. A legitimação da atuação do setor privado no atendimento do déficit habitacional brasileiro se dá pelo discurso da eficiência, que é reproduzido pelos empresários e pelo poder público (SHIMBO, 2010, p. 342).

Esta atuação conjunta de Estado, mercado imobiliário e capital financeiro foi possível pois, em 2004, o Poder Executivo federal elaborou uma nova política nacional de habitação em que especificava dois subsistemas de habitação: o subsistema de habitação de interesse social e o subsistema de habitação de mercado. Um dos objetivos dessa nova política era ampliar os mercados para atingir os setores populares, permitindo a otimização econômica dos recursos públicos e privados investidos no setor habitacional. No subsistema de habitação de mercado, ao qual Lúcia Shimbo se refere como "mercado capitalista de habitação", "podem estar presentes tanto o incentivo do Estado quanto os recursos públicos, mesmo que a apropriação do lucro da produção seja privada, regida sob uma lógica essencialmente capitalista" (SHIMBO, 2010, p. 53).

Segundo Luciana Royer, essa política de separação entre os subsistemas tinha como uma das prerrogativas a distinção das fontes de recursos e das faixas de renda que cada subsistema iria atingir. No entanto, a implementação gradual de alguns programas e incentivos fez com que a pretendida segmentação entre os dois subsistemas praticamente desaparecesse. Assim, o segmento econômico do mercado imobiliário se beneficiou duplamente ao conseguir acessar tanto as fontes de recursos destinadas à habitação de interesse social quanto aquelas destinadas à habitação de mercado (ROYER, 2009, p. 341).

Somando-se ao modelo de habitação de mercado, a fusão entre ramos distintos da produção de moradias é mais um fator que contribui para o controle cada vez maior da política habitacional pelo mercado imobiliário. As várias empresas com atividades distintas passaram a agir de forma integrada, de modo que essa fusão possibilitou que o todo o ciclo de produção da habitação se restringisse apenas à esfera interna do grupo corporativo:

A partir do momento em que uma determinada empresa que produz habitação passa a ser, ao mesmo tempo, proprietária de terras, incorporadora, construtora, financiadora e correspondente do governo na intermediação do financiamento ao consumidor, a própria lógica de estruturação do mercado se altera profundamente. O fato de um único agente perfazer o ciclo completo da produção da mercadoria "habitação" não se encaixa perfeitamente no esquema analítico, bastante presente no debate, que separa as funções de cada agente da produção do espaço urbano, como um todo (SHIMBO, 2010, p.54).

Consequentemente, essas empresas passaram a exercer cada vez mais influência sobre a Administração, dado o poder econômico que representam. Como resultado, esse poder 
econômico foi transformado em poder político, de modo que, atualmente, o planejamento urbano é definido pelo interesse dos produtores privados de habitação. Nesse sentido,

Soma-se, nas cidades, o enorme poder econômico e político dos proprietários de imóveis, sobretudo daqueles cuja atividade econômica está diretamente ligada ao mercado imobiliário, tanto de sua produção como de seu financiamento e gerenciamento dos ativos. Empreendedores imobiliários, empreiteiros de obras públicas e concessionários de serviços dialogam permanentemente com os executivos e legislativos municipais, e sobre estes exercem grande pressão e influência (ROLNIK et al, 2011, p.127).

Como ficou evidente, não é a produção privada de habitação que possui o condão de reduzir o déficit habitacional e efetivar os direitos à moradia e à cidade, sendo que cabe ao poder público a instituição de políticas públicas voltadas para esse fim. Nesse contexto, a pesquisa de Rolnik et al questiona o motivo pelo qual praticamente não há iniciativas municipais com essa finalidade. A hipótese era a de que seria por falta de recursos próprios e pela precariedade de condições administrativas das gestões locais. No entanto, essa hipótese não foi confirmada:

(...) concluímos que não é a falta de recursos financeiros e a dependência de outros entes federativos que têm impedido a formulação e implementação de ações autônomas, aderentes às necessidades locais e pactuadas nos âmbitos de participação instituídos, pois os municípios possuem, no mínimo, uma pequena margem financeira que permitiria a sua realização (ROLNIK et al, 2014, p. 163).

Segundo os autores, embora realmente exista certa dependência dos municípios, estes possuem certa margem de endividamento e instrumentos para a obtenção dos recursos necessários para instituírem suas próprias políticas habitacionais, mas, de modo geral, preferem não agir dessa forma, pois não veem necessidade em assumir a postura de agentes ativos. Atualmente, é mais vantajoso aos municípios apenas se adequarem para aderir aos programas de iniciativa do governo federal, especialmente o "Programa Minha Casa, Minha Vida".

Desse modo, uma das conclusões da pesquisa foi justamente a de que a forma como a produção de moradias está estruturada hoje beneficia diretamente as instituições privadas que atuam no mercado imobiliário:

(...) esses novos arranjos têm permitido um maior protagonismo do setor empresarial na promoção habitacional. O empresariado é brindado com uma maior liberdade de escolha sobre onde, como e quando pretende atuar, proporcionando toda uma nova mobilidade para a realização de negócios por parte das empresas, além de viabilizar a ampliação de seus mercados (ROLNIK et al, 2014, p. 159).

Portanto, a transferência de responsabilidade da esfera pública para a privada sobre a produção de moradia fez com que esta fosse reconhecida como mercadoria, evidenciando que, 
na verdade, nunca chegou a ser realmente encarada como um direito fundamental. Ao contrário: nessa perspectiva, moradia é somente um uso que o proprietário do imóvel tem à disposição depois de comprá-lo. Sem qualquer preocupação com a construção de um direito à cidade para todos, o planejamento urbano, que deveria assegurar a moradia adequada e promover a integração à cidade, passou a ser um instrumento a serviço do mercado imobiliário que, por sua vez, atende apenas aqueles que conseguem se adequar às condições por ele impostas, intensificando ainda mais o déficit habitacional e a segregação socioespacial.

No caso do "Reserva Dom Pedro", se de fato ocorrer sua aprovação, ficará ainda mais claro que o planejamento urbano de Campinas está a serviço do mercado imobiliário, uma vez que o empreendimento, produzido de forma privada e voltado para atender apenas aos abastados, além de não contribuir em nada com o interesse público da cidade, ainda agrava a dificuldade que as classes socioeconômicas mais vulneráveis enfrentam para ter acesso à moradia popular e à integração no espaço urbano.

6. Conclusão

Conforme exposto ao longo do trabalho, o fenômeno da "alphavillezação" da cidade, que inclui a eventual implantação do "Reserva Dom Pedro", implica necessariamente no entendimento de que o planejamento urbano não é realizado pela Administração Pública, mas sim pelo mercado imobiliário, ainda que indiretamente. Os serviços e equipamentos públicos deveriam ser programados para organizar a cidade de acordo com o interesse público, e não contrariá-lo.

Empreendimentos residenciais fechados, da natureza do "Reserva Dom Pedro", não apenas não atendem ao interesse coletivo, como também dificultam a efetivação dos direitos à cidade e à moradia adequada. Se o planejamento urbano é direcionado para favorecer o bom funcionamento do mercado imobiliário, é porque a Administração deixou de planejar a cidade, transferindo informalmente essa prerrogativa para os agentes de mercado, que se apropriam dos espaços urbanos e organizam o território da cidade não com base em direito, mas com base em dinheiro.

Assim, a partir do momento em que o planejamento urbano deixa de ser elaborado para atender ao interesse público e passa a ser direcionado para alavancar o mercado imobiliário, necessariamente fica excluída a possibilidade de assegurar o exercício de direitos fundamentais. Como é o mercado imobiliário quem define as regras tanto na política brasileira de habitação quanto na política urbana, os direitos à moradia e à cidade ficam subordinados à lógica de mercado. 
Por mais que conceitualmente exista uma diferenciação entre o que é Estado e quais são os seus papeis; e o que é o mercado e quais são as funções deste, na realidade parece que ambos se transformaram em um só, como se não houvesse mais a separação conceitual e funcional de cada um. O maior problema dessa fusão é que os objetivos de cada um, que deveriam ser diametralmente opostos, passam a ser os mesmos. O Estado deve visar ao bem estar social e à efetivação de direitos, enquanto a preocupação do mercado é única e exclusivamente a eficiência econômica e a obtenção de lucro. Quando o Estado passa a ter por objetivo a promoção dos interesses do mercado, abre mão de suas metas fundamentais. Se o Estado deixa de se preocupar com a promoção de direitos sociais, estes não serão efetivados, já que não serão garantidos por mais nenhuma outra instituição, inclusive o mercado.

A proliferação de condomínios e loteamentos fechados no espaço urbano, ao mesmo tempo em que satisfaz interesses privados do mercado imobiliário, inviabiliza o direito fundamental à moradia adequada e à cidade, já que o território, escasso, é utilizado exclusivamente para promover interesse privado e não interesse público.

Ademais, a comparação entre a atuação do poder público "como deveria ser" com "como realmente é" provocou uma reflexão acerca das barreiras jurídicas e políticas que os direitos fundamentais enfrentam para serem efetivados no sistema capitalista. Apesar de constarem no texto constitucional, o que faz de todas as pessoas titulares dos direitos, as condições para o exercício destes não é assegurada a todos, o que cria um grande abismo entre a previsão constitucional e a realidade material.Tratando especificamente dos direitos à moradia e à cidade, a diferença entre o que ocorre na prática e o que deveria ocorrer segundo a normativa constitucional é causada pelo fato de que o planejamento urbano é feito por pessoas que possuem interesse no desenvolvimento do mercado imobiliário, e, ao mesmo tempo, para pessoas que se beneficiam deste padrão de planejamento.

Como consequência, o município deixa de ser estruturado em função dos espaços públicos, e passa a ser pensado sob o prisma de espaços particulares distribuídos em sua área geográfica. Desse modo, o planejamento existente é falho, pois não cumpre com a sua finalidade institucional. Teoricamente, ainda que sejam privadas, as propriedades urbanas deveriam atender ao interesse público, conforme observado no conjunto normativo que foi explorado ao longo deste trabalho.

Na verdade, pode-se entender que a cidade que se apresenta nas normas jurídicas serve para ocultar a realidade de apropriação dos espaços urbanos. O planejamento é apresentado como algo que promove direitos e liberdade, quando na verdade oculta a 
concentração do território nas mãos de poucos e a segregação dos que não têm condição de pagar para ficar na cidade. O direito à cidade deixa de ser um direito decorrente da cidadania e passa a ser um título cada vez mais caro, decorrente de relações de consumo.

Conforme revelado pela pesquisa, o Administrador organiza a cidade de maneira que o capitalismo possa ser desenvolvido em toda sua exuberância, com a circulação de pessoas condicionada à circulação das mercadorias. A terra urbana se revela como uma das mercadorias mais caras da cidade. As questões urbanísticas mais graves, como o déficit habitacional e a gentrificação, ficam subordinadas à produção de imóveis que gerem, antes, o maior retorno possível ao investimento dos agentes de mercado. Com isso, a cidade é estruturada de tal maneira que alguns lugares se tornam privilegiados, mas sempre visando à produção, ao acúmulo de capital, e não ao desenvolvimento da cidadania.

Segundo a obra de Milton Santos, a integração à cidade deve ser proporcionada pelo Estado, e é condição mínima para que o indivíduo se afirme como cidadão:

Mais do que um direito à cidade, o que está em jogo é o direito a obter da sociedade aqueles bens e serviços mínimos, sem os quais a existência não é digna. Esses bens e serviços constituem um encargo da sociedade, através das instâncias do governo, e são devidos a todos. Sem isso, não se dirá que existe o cidadão (SANTOS, 2007, p. 158).

Na visão do autor, na cidade há cidadãos de diversas ordens ou classes, desde os ricos que possuem acesso irrestrito à cidade, até os pobres, que, por não possuírem meios, ficam restritos a uma parcela reduzida da cidade, de modo que a rede urbana ganha significados diversos segundo a posição financeira do indivíduo. Num extremo estão aqueles que podem utilizar todos os recursos existentes e, no outro, os que são "prisioneiros do lugar", dependentes das condições locais de onde habitam, sem participar do que realmente é a cidade (SANTOS, 2007, p. 140).

Enfim, o "Reserva Dom Pedro" não serve ao direito à moradia, mas serve apenas a quem tem condições de comprar moradia. A partir do momento em que moradia é vista como uma mercadoria qualquer, a lógica de mercado que se instala regulamenta todas as relações sociais, o que inviabiliza a efetivação do direito à moradia, que só pode ocorrer por meio de promoção de políticas urbanas que sirvam para reduzir o déficit habitacional. Ao se autorizar que uma gleba de terras seja urbanizada para se venderem moradias de alto padrão, o interesse privado é o único presente, ou pelo menos o interesse predominante. 


\section{REFERÊNCIAS BIBLIOGRÁFICAS}

\section{Legislativas}

BRASIL. Assembleia Nacional Constituinte, Constituição da República Federativa do Brasil, 1988. Disponível em: http://www.planalto.gov.br/ccivil_03/Constituicao/Constituicao.htm (último acesso em 28/01/2017).

Congresso Nacional. LEI no 6.766/79, Lei do Parcelamento do Solo Urbano. Disponível em: http://www.planalto.gov.br/ccivil_03/leis/L6766.htm (último acesso em 28/01/2017).

LEI no 10.257/2001, Estatuto da Cidade. Disponível em: http://www.planalto.gov.br/ccivil_03/leis/LEIS_2001/L10257.htm (último acesso em 28/01/2017).

CAMPINAS. CÂMARA DE VEREADORES. LEI no 6.031/1988, Lei de Uso e Ocupação do Solo. Disponível em: http://www.campinas.sp.gov.br/arquivos/seplama/lei_6031.pdf (último acesso em 28/01/2017).

CÂMARA DE VEREADORES. LEI no 9.199/1996, Plano Local de Gestão Urbana de Barão Geraldo. Disponível em: https://bibliotecajuridica.campinas.sp.gov.br/index/visualizar/id/91794 (último acesso em 28/01/2017).

CÂMARA DE VEREADORES. Lei Complementar no 15/2006, Plano Diretor. Disponível em: https://bibliotecajuridica.campinas.sp.gov.br/index/visualizar/id/89986 (último acesso em 28/01/2017).

\section{Bibliografias}

FEIOCK, Richard; TAVARES, Antonio; LUBELL, Mark. Policy instrument choices for growth management and land use regulation. The Policy Studies Journal, v. 36, n. 3, 2008, p. 461-480.

FREITAS, Eleusina Lavôr Holanda de. Loteamentos fechados. Tese de doutorado. Faculdade de Arquitetura e Urbanismo da Universidade de São Paulo. São Paulo, 2008.

HARVEY, David. A produção capitalista do espaço. Tradução Carlos Szlak. São Paulo: AnnaBlume, 2005.

MASTRODI, Josué; SILVEIRA, Suzana Maria Loureiro. Sobre a promoção do direito à moradia: um estudo à luz da política urbana do município de Campinas. Revista de Direito da Cidade, v. 08, n. 1, 2016, p.1-28.

RIBEIRO, Joana; MOREIRA, Tomás. A. A política fundiária nos planos locais de habitação: entre a demanda terra e o direito de propriedade. Ambiente Construído, Porto Alegre, v. 14, n. 4, 2014, p. 217-232.

RIBEIRO, Tarcyla. O Planejamento Urbano como Instrumento Garantidor do Direito à Cidade. Revista de Direito da Cidade, v. 04, n. 01, 2012, p.71-90. 
ROLNIK, Raquel. A Construção de uma Política Fundiária e de Planejamento Urbano para o País Avanços e Desafios. Políticas Sociais (IPEA), v. 12, 2006, p. 199-210.

ROLNIK, Raquel; CYMBALISTA, Renato; NAKANO, Kazuo. Solo urbano e habitação de interesse social: a questão fundiária na política habitacional e urbana do país. Revista de Direito da ADVOCEF, v. 1, 2011, p. 123-158.

ROLNIK, Raquel; IACOVINI, Rodrigo; KLINTOWITZ, Danielle. Habitação em municípios paulistas: construir políticas ou 'rodar' programas? Revista Brasileira de Estudos Urbanos e Regionais (ANPUR), v. 16, 2014, p. 149-165.

ROLNIK, Raquel; KLINK, Jeroen. Crescimento Econômico e Desenvolvimento Urbano: por que nossas cidades continuam tão precárias? Novos Estudos CEBRAP (Impresso), v. 89, 2011, p. 89109.

ROYER, Luciana. Financeirização da Política Habitacional: Limites e Perspectivas. São Paulo: Annablume, 2014.

SANTOS, Milton. O Espaço do Cidadão, Nobel: São Paulo, 5ạ ed., 2000.

SHIMBO, Lucia. Habitação social de mercado: a confluência entre Estado, empresas construtoras e capital financeiro. 1. ed. Belo Horizonte: C/Arte, 2012.

O aquecimento imobiliário e o mercado de habitação na área central de São Paulo (20012010). EURE (Santiago. Impresa), v. 39, 2013, p. 215-235.

Trabalho enviado em 03 de abril de 2017.

Aceito em 25 de maio de 2017. 